\title{
Stable oxygen and hydrogen isotopic tracers in Amazon shelf waters during Amasseds
}

\section{Traceurs isotopiques de l'oxygène stable et de l'hydrogène dans les eaux côtières amazonienne durant le programme Ammaseds}

\author{
Jonathan D. Karr *, William J. Showers \\ North Carolina State University, Department of Marine, Earth and Atmospheric Sciences, Raleigh, NC 27695, USA
}

Received 18 September 2001; received in revised form 17 December 2001; accepted 17 December 2001

\begin{abstract}
A detailed hydrographic survey of the water column of the Amazon shelf was performed using stable oxygen and hydrogen isotopes to determine the source and fate of waters on the shelf. $\delta^{18} \mathrm{O}-\mathrm{H}_{2} \mathrm{O}$ and $\delta \mathrm{D}$ measurements were made on water column samples from approximately 60 stations (three depths per station) which were each collected during four Amasseds (A Multidisciplinary Amazon Shelf SEDiment Study) cruises: I8909-August 1989, falling river discharge; I9002-March 1990, rising river discharge; I9004-May 1990, peak discharge; I9113-November 1991, minimum discharge. Isotopes were compared with salinity and temperature measurements in order to identify water masses and mixing. The characteristics (salinity, temperature, $\delta^{18} \mathrm{O}, \delta \mathrm{D}$ and $d$ ) are proposed for the following end-number water masses: river water, open ocean surface water $(0-100 \mathrm{~m})$ and open ocean intermediate water $(>300 \mathrm{~m})$. River water: salinity $=0$; temperature $\approx 27-29{ }^{\circ} \mathrm{C} ; \delta^{18} \mathrm{O}=-4.2$ to -6.8 per mil; $\delta \mathrm{D} \approx-22.1$ to -38.9 per mil; $d=9.4$ to 17.0 per mil (compare to $d=10$ for Meteoric Water Line). Open ocean surface water $(\approx 0-100 \mathrm{~m})$ : salinity $\approx 35$ to 37 ; temperature $\approx 25-29{ }^{\circ} \mathrm{C} ; \delta^{18} \mathrm{O} \approx-1$ to +2 per mil; $\delta \mathrm{D} \approx-3.6$ to +10.2 per mil. Open ocean intermediate water $(\gtrsim 300 \mathrm{~m})$ : salinity $=34.6$ to 35.0 ; temperature $=4.8$ to $9.6^{\circ} \mathrm{C} ; \delta^{18} \mathrm{O}=-0.2$ to +0.3 per mil; $\delta \mathrm{D}=-8.72$ to -0.95 per mil. Amazon river water follows a seasonal isotopic cycle in response to basin hydrologic processes. River water mixes with equatorial surface ocean water and intermediate ocean waters originating in mid-to-high southern latitudes. Near-surface waters in the region of North Brazil Current retroflection were identical in isotope-salinity space to waters on the outer shelf during November 1991. (C) 2002 Ifremer/CNRS/IRD/Éditions scientifiques et médicales Elsevier SAS. All rights reserved.
\end{abstract}

\section{Résumé}

Un suivi hydrologique de la colonne d'eau du plateau continental au débouché de l'Amazone a été réalisé en utilisant les isotopes de l'oxygène stable et de l'hydrogène pour déterminer l'origine et la destinée des eaux sur la plate-forme. Les mesures des $\delta^{18} \mathrm{O}-\mathrm{H}_{2} \mathrm{O}$ et $\delta \mathrm{D}$ ont été réalisées à soixante stations (trois niveaux par station) durant quatre campagnes Amasseds (A multidisciplinary Amazon shelf sediment study) : la première en août 1989 en période d'apports décroissants, la seconde en mars 1990, quand ces apports croissent, la troisième lors du pic de la décharge (mai 1990) et la dernière en novembre 1991, lors du minimum d'apports. Les isotopes ont été comparés à la salinité et à la température pour identifier les masses d'eaux et leurs mélanges. L'article propose les caractéristiques (salinité, température, $\delta^{18} \mathrm{O}, \delta \mathrm{D}$ et $d$ pour les masses d'eau suivantes: eau de rivière, eau océanique de surface $(0$ à $100 \mathrm{~m})$ et eau océanique intermédiaire (>300 m). Les eaux amazoniennes suivent un cycle saisonnier isotopique en réponse aux processus hydrologiques du bassin. Les eaux du fleuve se mélangent avec l'eau océanique équatoriale de surface et les eaux intermédiaires originaires des latitudes moyennes ou élevées de l'hémisphère Sud. En novembre 1991, les eaux proches de la surface dans la région de rétroflexion du courant Nord du Brésil

\footnotetext{
* Corresponding author.

E-mail address: jkarr@duke.edu (J.D. Karr).
} 
sont identiques, en termes de salinité et de rapports isotopiques, aux eaux à l'extérieur du plateau continental. (C) 2002 Ifremer/CNRS/IRD/Éditions scientifiques et médicales Elsevier SAS. Tous droits réservés.

Keywords: Amazon; Isotope; ${ }^{18} \mathrm{O}$; Deuterium; Hydrography

Mots clés: Amazone; Isotopes; ${ }^{18} \mathrm{O}$; Deutérium; Hydrologie

\section{Introduction}

The Amazon is the world's largest river, supplying approximately one-fifth of the global runoff to the ocean Coltman. 1968. The Western Equatorial Atlantic adjacent to the Amazon shelf is the only known region of large-scale cross-equatorial heat transport by surface currents Gordon 1986. The river-shelf system is tied into Atlantic salinity distributions and global ocean circulation. Isotopic identification of water masses in the region improves the understanding of water mass distributions here. The current study is the first to systematically address the $\delta^{18} \mathrm{O}-$ salinity relationships in shelf waters off the mouth of the Amazon. The Amazon outflow is so great that estuarine-like conditions are imposed upon the shelf Gibbs, 1970. The general observation was made during the four Amasseds cruises that large event-scale variations in the shelf water column are superimposed on a seasonal cycle of river discharge and North Brazil Current (NBC) transport and eastward retroflection. Event-scale changes may be greater in amplitude than seasonal changes in some cases Lentz, 1995: Lent and Limeburner, 1995). The Amazon outflow is advected into the North Atlantic by the NBC, which runs northwest along the Amazon Shelf. Bruce (1984) showed that the NBC bifurcates between $4^{\circ} \mathrm{N}$ and $8^{\circ} \mathrm{N}$ into the coastal Guiana Current and a retroflecting North Equatorial Countercurrent (NECC) from July through September. Recent studies and modeling have shown that plume behavior is highly coupled to wind stress as opposed to NBC influences (Paluszkiewicz and Chao 1991: Gever et al. 1991: Limeburner and Beardsley, 1989; Lentz and Limeburner, 1995; Lentz, 1995. Residence time and total storage of fresh water on the shelf during Amasseds was calculated from salinity balances Limeburner, 1992), with maxima in March $\left(\approx 380 \mathrm{~km}^{3}\right.$ and $\approx 22$ days $)$ and minima in November $\left(\approx 140 \mathrm{~km}^{3}\right)$ and May ( $\approx 15$ days $)$.

The Amazon Basin covers an area of about 6.4 million $\mathrm{km}^{2}$ and contains the largest remaining stand of tropical rainforest in the world Salati_et al. 1979:_Richey et al. 1989. The basin drains about one-third of South America's land surface, and the main channel, the UrubambaUcayali-Amazon River, is about $6500 \mathrm{~km}$ in total length, with about one thousand tributaries (Salati and Vose, 1984).

Analogous studies in other regions have examined the $\delta^{18} \mathrm{O}$ and $\delta \mathrm{D}$ signals of waters from moderately large rivers mixing with the ocean. Torgerson (1979) measured the $\delta^{18} \mathrm{O}$ and $\delta \mathrm{D}$ of 36 North American rivers from Florida to New Brunswick during April-May 1975. The $\delta^{18} \mathrm{O}-$ salinity mix- ing lines for coastal waters generally have increasing slope with increasing latitude. This is because the fresh water end-member of this mixing line is more depleted in ${ }^{18} \mathrm{O}$ at higher latitudes, while open ocean isotopic values are fairly constant. However, in some regions, hydrography of continental shelves and river basin hydrology can complicate the simple river-ocean mixing relationship.

\section{Materials and methods}

Cruises were timed so as to coincide with different river stages, and will be referred to as such: falling water (August 1989), rising water (March 1990), peak discharge (May 1990) and minimum discharge (November 1991). The cruises also coincided with different parts of the annual cycles of modeled NBC flow and windstress. All data referred to here resulted from measurements and water samples taken during the large-scale hydrographic survey (Leg 3) of each cruise by Amasseds researchers. Hydrographic data from CTD measurements performed aboard the $R V$ Iselin during the Amasseds cruises were supplied by DeMaster, Limeburner and Beardsley.

Approximately sixty stations were sampled on each cruise. Shore-perpendicular transects with stations spaced in a fairly regular manner were followed during the sampling (Fig. 1). The stations cover a broad spectrum of salinity, turbidity, depth and energy conditions, and give a representative picture of the range of water column variability on the shelf. Several stations were designed to sample particular features, such as the river mouth, the turbid coastal waters north of the river mouth, high productivity regions, and deep waters seaward of the shelf break. At each station, approximately three depths were sampled: surface, intermediate (generally near the base of the halocline), and nearbottom.

Water samples were collected from hydrocasts by withdrawal through the Niskin bottle spigots into 60-ml syringes, then expelled through Whatman 0.45- $\mu \mathrm{m}$ GF/F filters into glass 45-ml serum bottles. Samples were poisoned with saturated $(7 \%) \mathrm{HgCl}_{2}$ solution during the bottling, stored out of light, and kept refrigerated. A set of 811 samples (including duplicates) was equilibrated with puri fied tank $\mathrm{CO}_{2}$ according to a modified version of the method of Epstein and Mayeda_(1953). During the equilibration phase, the samples were maintained at $50 \pm 0.1{ }^{\circ} \mathrm{C}$, for at least $12 \mathrm{~h}$, then cryogenically purified through a double trap system. Isotopic analyses were performed with a Finnigan 

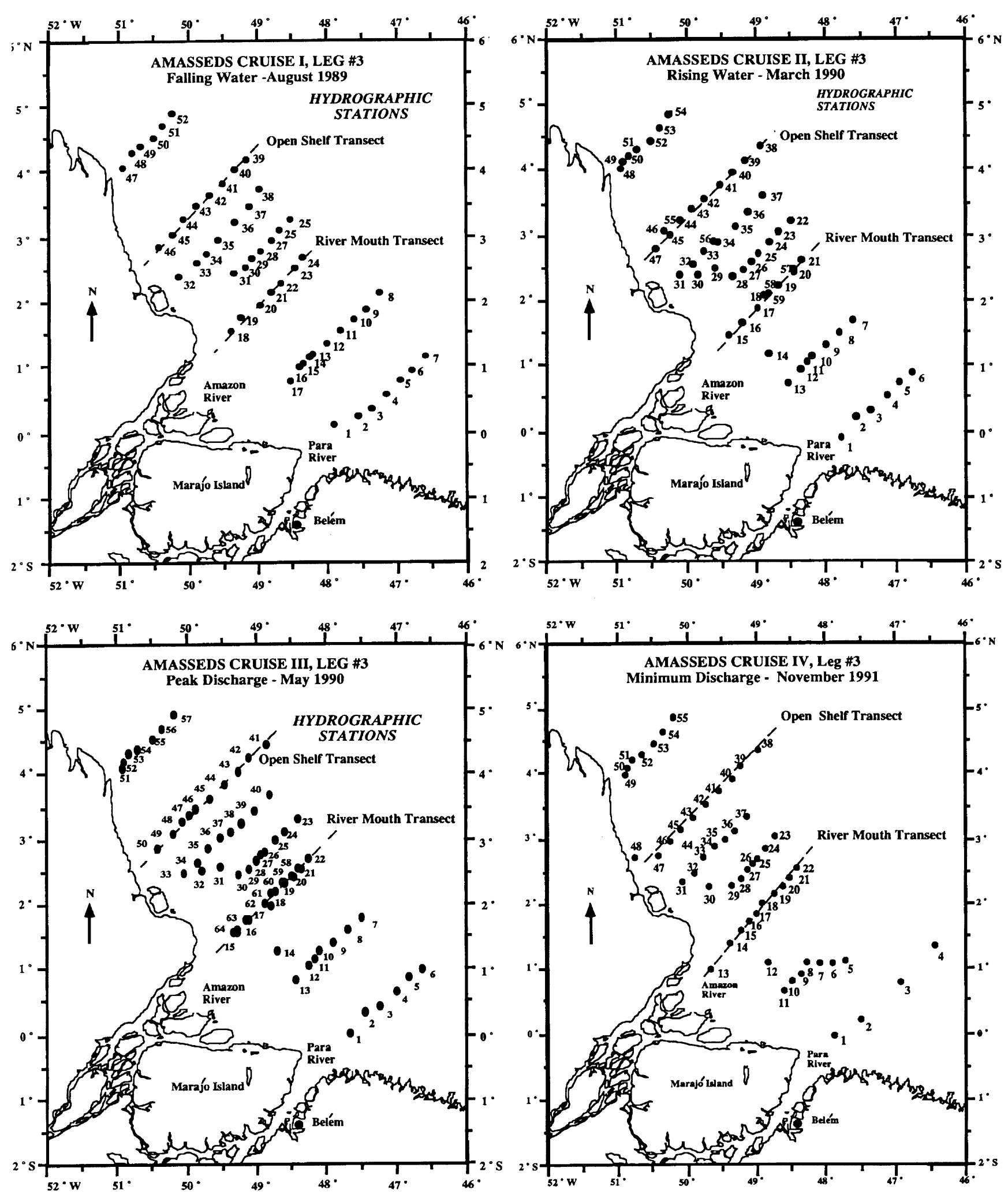

Fig. 1. Station locations for the four Amasseds cruises. The river mouth, the shelf break/upper slope, the river plume, and high turbidity coastal areas north of the river were included in the shelf survey. All but the outer-most stations are within shelf waters $($ depth $<200 \mathrm{~m})$.

Mat 251 ratio mass spectrometer with an 18 port computercontrolled automatic multiple inlet system. Two internal laboratory standards, NCSU-Smow and IMSL-Smow, were processed along with the samples in a ratio of approximately one standard per five samples, with a standard deviation of approximately $\sigma_{1}= \pm 0.1$ per mil $\delta^{18} \mathrm{O}_{\text {Smow }}$. 
Analyses for $\delta \mathrm{D}$ were performed for 66 samples, approximately equally divided among the four cruises. Samples with unusual $\delta^{18} \mathrm{O}$ values were analyzed, as well as samples representing a range of salinities so as to establish a $\delta \mathrm{D}$-salinity mixing line and $\delta \mathrm{D}-\delta^{18} \mathrm{O}$ mixing line for each cruise. Hydrogen gas for $\delta \mathrm{D}$ analyses was extracted according to a modified version of the method of Coleman et al_(1982). Approximately $60 \mathrm{mg}$ of special zinc reagent F-20 (Indiana University, Dept. of Chemistry) was added to a 9-mm glass breakseal along with a 1- $\mu$ l glass capillary tube of sample water. Evacuated sample breakseals were placed in a $500-{ }^{\circ} \mathrm{C}$ reaction oven for $30 \mathrm{~min}$ to allow reduction of the water by the zinc, and the resulting hydrogen gas was analyzed on the mass spectrometer. Standards were processed at the rate of approximately one per five samples. Both V-Smow (a distilled international standard water) and IMSL-Smow (an internal marine standard water) were used. Precision of standards was approximately $\sigma_{1}= \pm 1$ per mil.

\section{Results}

The results of oxygen isotope analyses of Amazon shelf waters during Amasseds are plotted against salinity (Fig. 2). For each cruise, the expected linear pattern emerges, with the isotopically negative fresh river water mixing with isotopically positive high salinity ocean water. Some data points show varying degrees of positive and negative deviations about the mixing lines, indicating the probability of non-conservative processes (evaporation and precipitation). A plot of $\delta^{18} \mathrm{O}$ vs. depth (Fig. 3) reveals that the deepest waters actually fall within the range of the isotopic composition of surface ocean waters, but can be distinguished by their much colder temperatures and very narrow isotopic range.

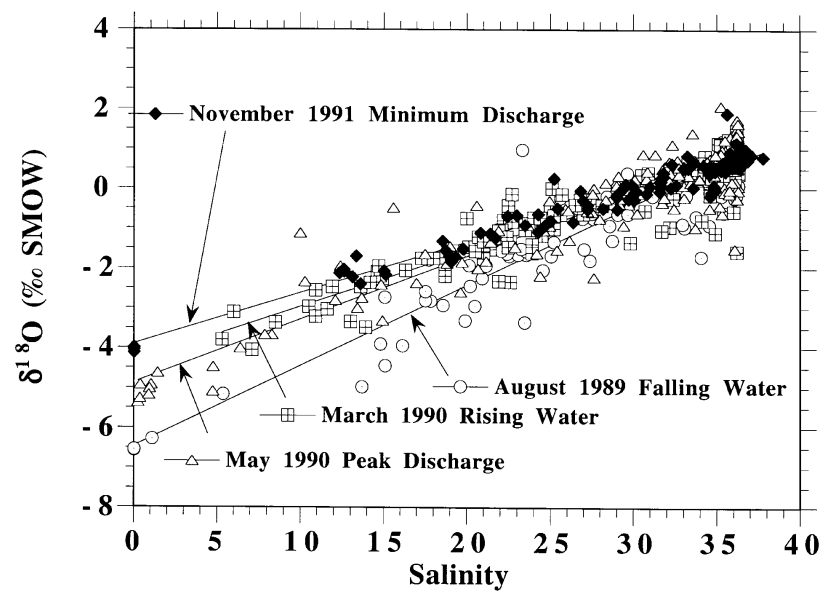

Fig. $2 .{ }^{18} \mathrm{O}$ depleted river water mixes with ${ }^{18} \mathrm{O}$ enriched ocean waters on the shelf. The slope of the mixing line is controlled by the river end-member, which varies seasonally in response to Amazon Basin hydrology.

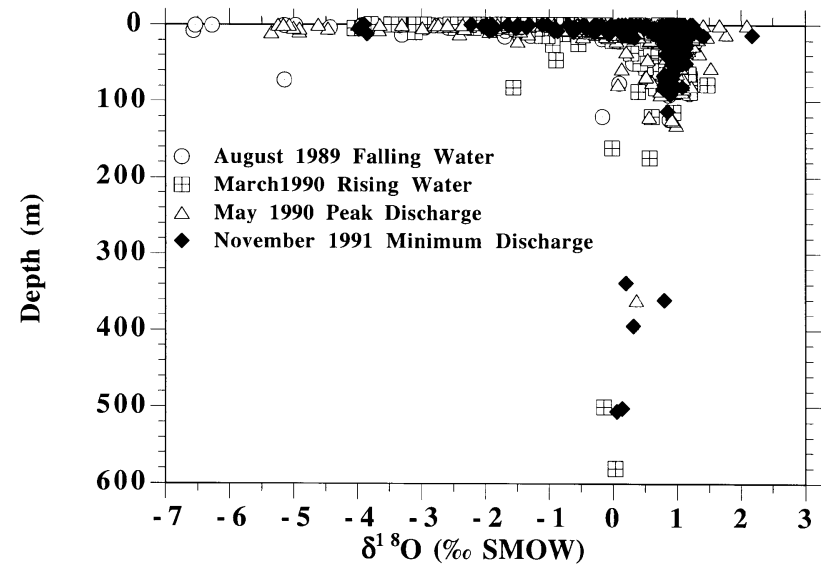

Fig. 3. Shallow waters show an isotopic range between river and open ocean values. Deeper waters formed beyond the shelf break are tightly constrained isotopically.

The following end-member water masses are proposed:

- river water: salinity $=0$; temperature $\approx 27-29^{\circ} \mathrm{C}$; $\delta^{18} \mathrm{O}=-4.2$ to -6.8 per mil; $\delta \mathrm{D}=-22.1$ to -38.9 per mil; $d=9.4$ to 17.0 per mil (compare to $d=10$ for Meteoric Water Line).

- open ocean surface water $(\approx 0-100 \mathrm{~m})$ : salinity $\approx 35$ to 37 ; temperature $\approx 25-29^{\circ} \mathrm{C} ; \delta^{18} \mathrm{O} \approx-1$ to +2 per mil; $\delta \mathrm{D} \approx-3.6$ to +10.2 per mil.

- open ocean intermediate water $(\gtrsim 300 \mathrm{~m})$ : salinity $=34.6$ to 35.0 ; temperature $=4.8$ to $9.6 \mathrm{C}$; $\delta^{18} \mathrm{O}=-0.2$ to +0.3 per mil; $\delta \mathrm{D}=-8.72$ to -0.95 per mil.

\section{Discussion and conclusion}

\subsection{Seasonal cycle of river mouth $\delta^{18} \mathrm{O}$}

Seasonal variations occur in the isotopic composition of the river end-member. Fig. 4 shows the $\delta^{18} \mathrm{O}$ values at the river mouth superimposed on the annual river discharge cycle. The $\delta^{18} \mathrm{O}$ values obtained for the river end-member on the Amasseds cruises agree reasonably well with those of Reis et al (1977) for their 1973-1974 data set, with a slight phase lag in the seasonal isotopic progression of the newer data vs. the older data. This may be attributable to interannual and spatial variability, especially since Amasseds measurements span three calendar years, rather than representing one continuous annual cycle. Interannual variations of about 1.5 per mil $\delta^{18} \mathrm{O}$ appear in the data of Reis ef al (1977) for river stations in the Amazon estuary. River water (at the mouth) $\delta^{18} \mathrm{O}$ is more positive during the rainy season which includes the rising water period in March and the peak discharge period in May, than during falling water in August. This seems to contradict the 'amount effect' by which precipitation and surface water $\delta^{18} \mathrm{O}$ in a particular location should be more negative during periods of high precipitation and low evaporation, and more positive during 


\begin{tabular}{|llll|}
\hline TIMELINE & FOR & FIELD & PROGRAM \\
\hline
\end{tabular}

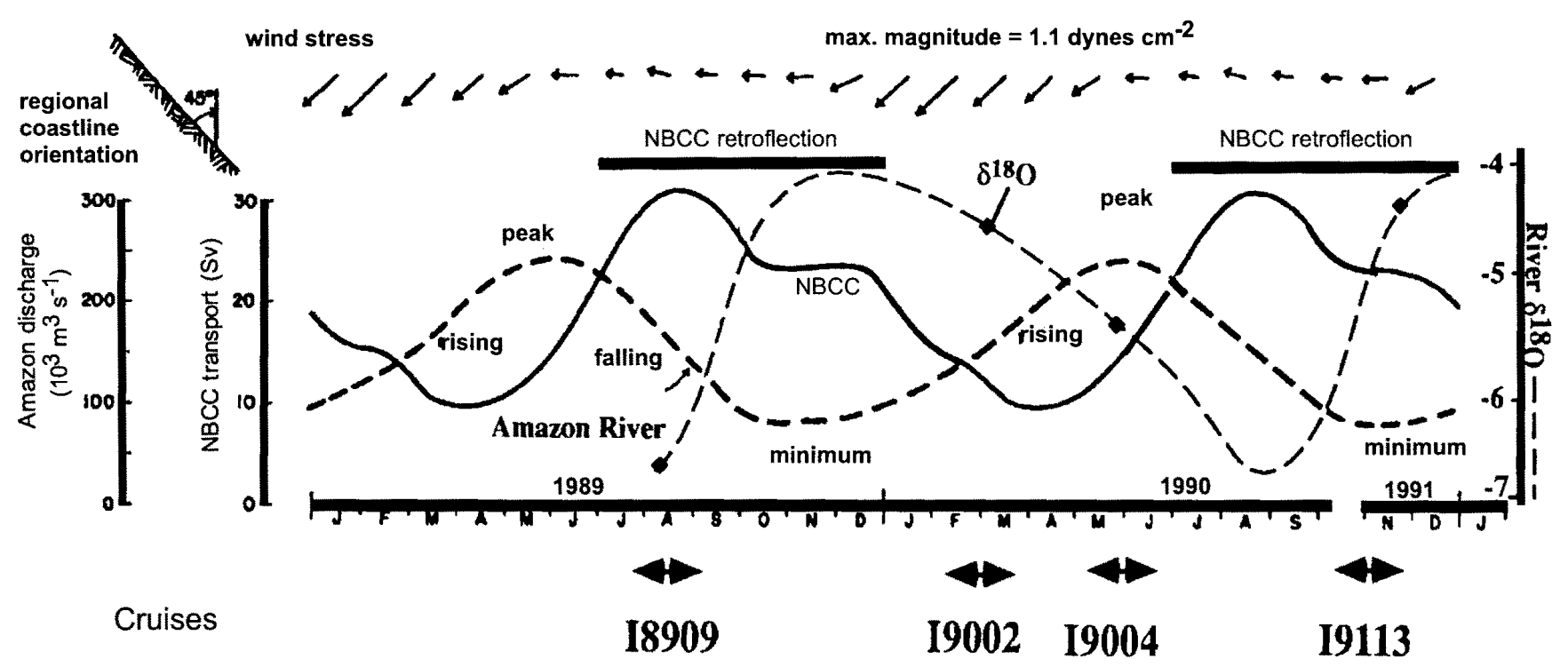

Fig. 4. The annual cycle of Amazon River discharge plotted with the annual variation of $\delta^{18} \mathrm{O}$ at the river mouth during Amasseds. The isotopic signal appears to be a phase-shifted mirror-image of the discharge cycle. This may be due to the lag time in delivery of isotopically depleted western Amazonian waters to the mouth.

periods of low precipitation and high evaporation which causes isotopic enrichment of residual waters, as observed by previous studies in the interior basin, e.g. Salati et al 1979]. The discrepancy is due to basin residence-induced lag time of isotopically depleted waters of western Amazon origin in reaching the mouth after the less isotopically depleted flood wave from the eastern part of the basin has already passed. Some Andean tributaries are as negative as -9 to -15 per mil Salati et al. 1980). The magnitude of river discharge shows a phase lag going downstream, and the seasonal discharge variation is greater downstream Richey et al. 1989) so that in August during falling water, waters of upstream (western) origin comprise a greater proportion of the discharge at the mouth than during the wetter period of March-May. Richey et al (1989) calculate a total of 65 days transit time for the flood wave from Sao Paulo Olivença to Obidos, a 2000-km reach. This is based on residence times of the flood wave at sequentially downstream sections of the mainstem, although the flood wave does not move downstream in a uniform manner. The actual transit time for an individual parcel of water along this reach is about one third as great (Devolet al.,1987) as opposed to the migration of the flood wave, or peak river level. The additional flood wave transit time for the reach from Obidos to the mouth $(\approx 700 \mathrm{~km})$ may be about 20 days. Thus western Amazon water from precipitation during May and June, when precipitation is high and its $\delta^{18} \mathrm{O}$ is generally more negative, does not reach the mouth in greatest proportion until August. Longinelli_and_Edmond 1983] found river water $\delta^{18} \mathrm{O}$ in the downstream reaches more negative in July, during falling water, than during peak discharge in May. In November 1991, during the period of minimum discharge and low precipitation, the river-mouth $\delta^{18} \mathrm{O}$ reached its least negative values. This is due to the amount effect, as described above, along with the aforementioned phase lag. In general, the isotopic cycle of the river mouth is a somewhat phase-shifted mirror-image of the discharge cycle. The interpretation is strengthened by the results of $\delta \mathrm{D}$ analyses of river mouth water, which follow the relationship determined by the global meteoric mixing line $\left(\delta \mathrm{D}=8 \delta^{18} \mathrm{O}+10\right)$ very closely and also show the most negative value at falling water. Excess deuterium enrichment $(d)$ is greatest during falling water. This would be expected, since at this time a greater proportion of river water comes from the western basin waters which have

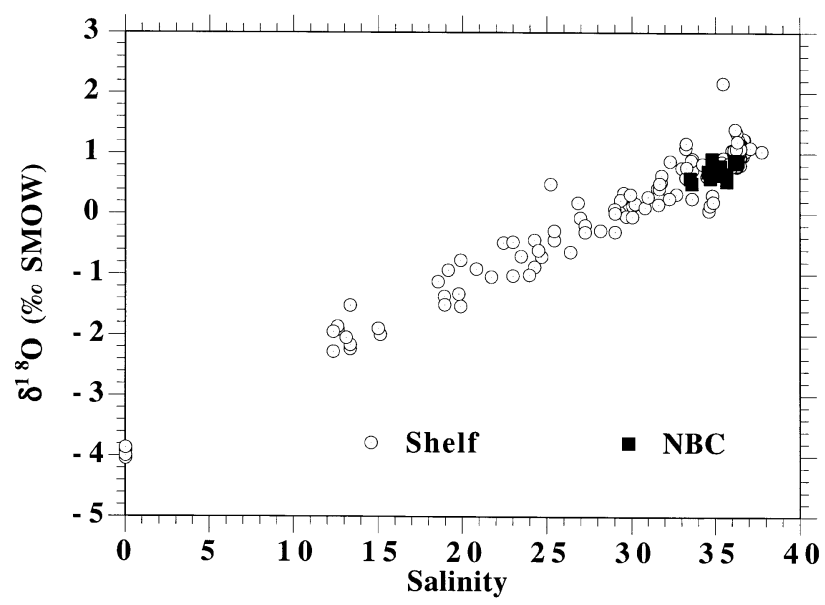

Fig. 5. Samples taken from the NBC retroflection region during November 1991 fall into the $\delta^{18} \mathrm{O}$-salinity field of Amazon shelf full marine waters, indicating that the shelf is the source of these NBC waters. 

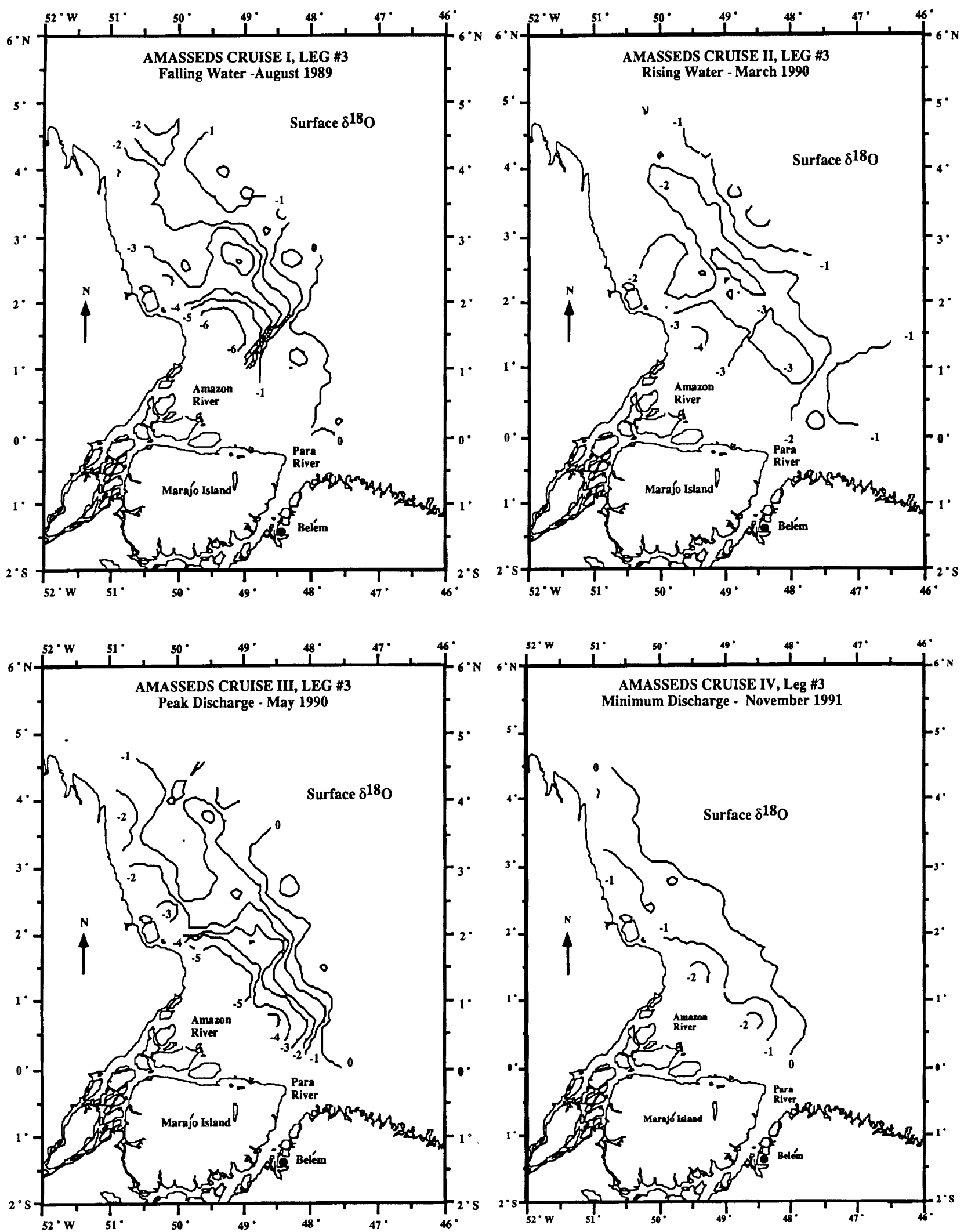

Fig. 6. Contours of $\delta^{18} \mathrm{O}$ in surface waters indicate the extent of the river plume and the mixing gradient with open ocean waters on the shelf. Since modification of $\delta^{18} \mathrm{O}$ by non-conservative processes such as evaporation and precipitation appears to be minimal of here, the $\delta^{18} \mathrm{O}$ contours correspond well with those of salinity. 

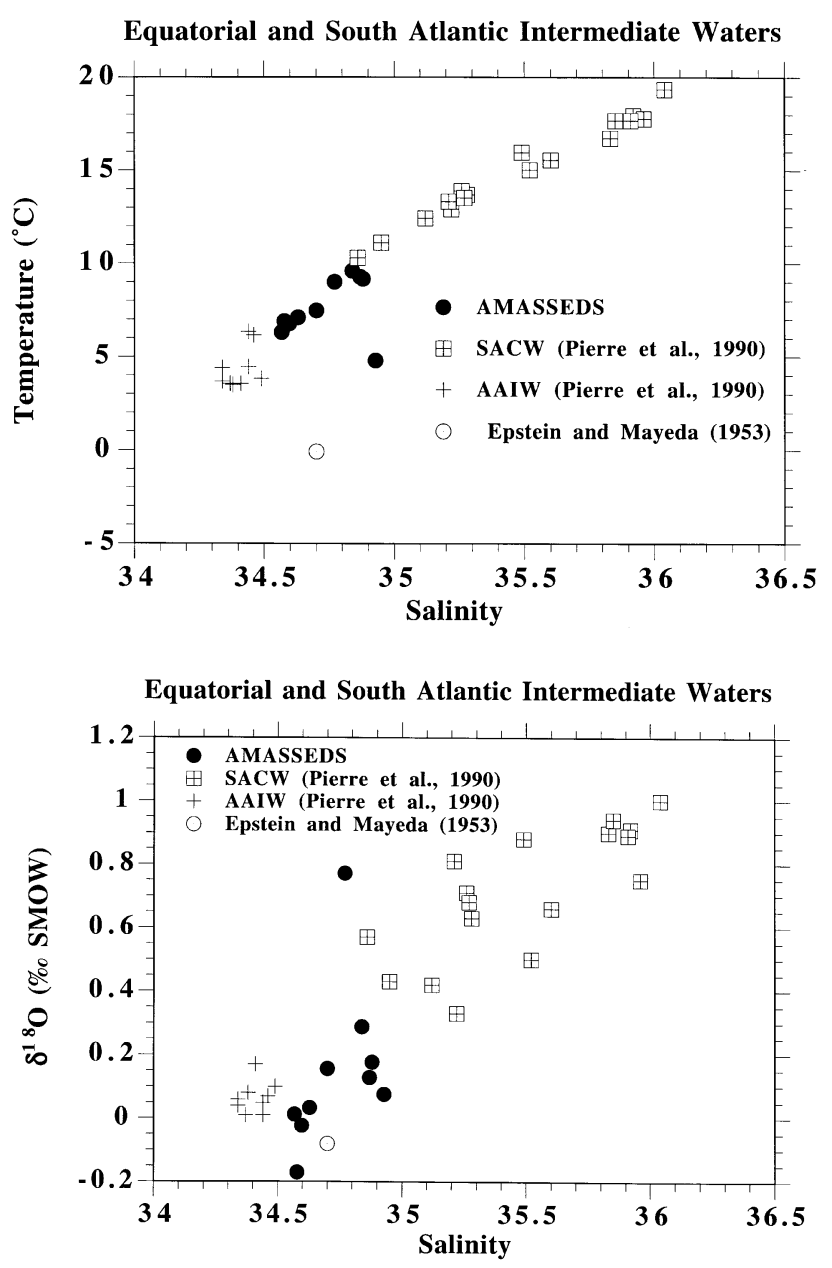

Fig. 7a,b. In both $\mathrm{T}-\mathrm{S}$ and $\delta^{18} \mathrm{O}-\mathrm{S}$ space, samples from beyond the Amazon shelf break fall between South Atlantic central water and Antarctic intermediate water.

undergone extensive recycling and kinetic fractionation, depleting them along $\delta \mathrm{D} / \delta^{18} \mathrm{O}$ slopes less than 8, the slope of the Meteoric Water Line as defined by Craig (1961).

\subsection{Samples from the NBC retroflection area}

At the end of the November 1991 cruise, during the return trip of the $R V$ Iselin to Miami, 13 samples were collected for $\delta^{18} \mathrm{O}-\mathrm{H}_{2} \mathrm{O}$ and $\delta \mathrm{D}$ in the general vicinity of the NBC retroflection $\left(6^{\circ} 21^{\prime} \mathrm{N}\right.$ to $10^{\circ} 46^{\prime} \mathrm{N}$ and $43^{\circ} 46.4^{\prime} \mathrm{W}$ to $50^{\circ} 02^{\prime}$ W.) Four samples were collected from depths of 95-98 m, while the rest were collected at a depth of 1-2 m. The samples represent waters of the NBC, including those that have resided on the Amazon shelf and contain Amazon outflow. Surface samples are generally less saline than deep samples, owing to mixing with low salinity Amazon lenses. The isotope-salinity coordinates of the NBC samples fall squarely in the marine end-member range for the November (minimum discharge) cruise (Fig. 5). The association of NBC retroflection waters with Amazon shelf waters was previously demonstrated by Moore and Astwood (1991). who measured natural and artificial radium tracers in these

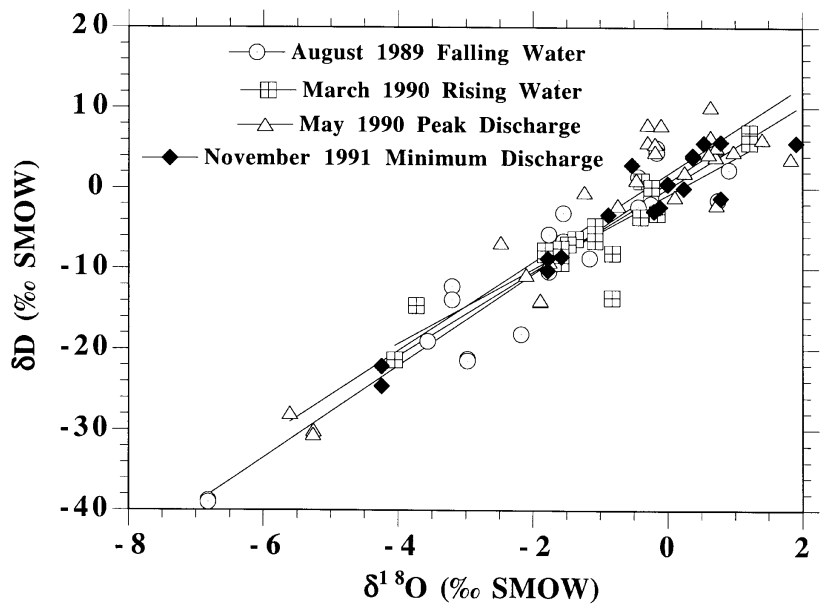

Fig. 8. $\delta \mathrm{D}-\delta^{18} \mathrm{O}$ slopes are similar for all seasons, indicating little effect from shelf residence time or atmospheric processes on isotopic composition of shelf waters.

waters during July and September 1990 during Amasseds. Excess $224 \mathrm{Ra}$ (half-life $=3.6$ days) of $8 \mathrm{dpm} 100 \mathrm{l}^{-1}$ occurred in waters of 31-34 salinity in the retroflection area, compared with excess $224 \mathrm{Ra}$ of $15-20 \mathrm{dpm} 100 \mathrm{l}^{-1}$ in waters of similar salinity in the river-ocean mixing zone on the shelf. This indicated a transit time of 5 days for Amazon waters advected north to the retroflection area, requiring sustained currents of $50 \mathrm{~cm} \mathrm{~s}^{-1}$. Apparently the stable isotopic composition of these waters was not significantly altered during this transit time. Moore (pers. comm., 1991) believes that the waters in this region are chiefly of Amazon shelf origin. This is in agreement with the observations of previous investigators (Neumann, 1969) regarding the advection of Amazon waters into the North Atlantic.

\section{3. $\delta^{18} O, \delta D$ and water masses}

Surface waters of the shelf record the extent of the river plume with $\delta^{18} \mathrm{O}$ (Fig. 6). The open ocean surface water is likely a mixture of local surface and subsurface waters with subtropical intermediate water (SIW). Available data representing SIW Craig and Gordon, 1965) indicate that it should fall in the range of $\delta^{18} \mathrm{O}+0.5$ to +1.0 per mil. $\mathrm{T}-\mathrm{S}$ characteristics of Amasseds samples above $24^{\circ} \mathrm{C}$ correspond well to SIW, as defined in Sverdrup. Johnson and Eleming (1946). The Amasseds samples taken from $\approx 300 \mathrm{~m}$ and deeper seem to be continuous in $\mathrm{T}-\mathrm{S}$ and $\delta^{18} \mathrm{O}-\mathrm{S}$ space (Fig. 7a, b) with the gradation of South Atlantic central water into Antarctic intermediate water.

Values of $\delta \mathrm{D}$ are plotted against $\delta^{18} \mathrm{O}$ in Fig. 8. Some samples showed evidence of excess evaporation resulting in kinetic fractionation and enrichment of residual waters along $\delta \mathrm{D} / \delta^{18} \mathrm{O}$ slopes less than that for the $\delta \mathrm{D}$ vs. $\delta^{18} \mathrm{O}$ mixing line for that cruise. However, these plots indicate little overall atmospheric modification of surface waters on the shelf, such that their properties are not significantly determined by their residence time on the shelf. 
In conclusion, Amazon River water mixes in conservative fashion with surface and intermediate ocean waters on the shelf, with minimal modification by atmospheric processes on the shelf. The seasonal cycle of river mouth $\delta^{18} \mathrm{O}$ is likely controlled by a combination of amount effect and lag time for isotopically depleted western basin waters to reach the mouth. Ocean intermediate waters appear to represent South Atlantic central water mixing with Antarctic intermediate water.

\section{References}

Bruce, J.G., 1984. Comparison of eddies off the north Brazilian and Somali coasts. J. Phys. Oceanogr. 14, 825-832.

Coleman, M.L., Shepherd, T.J., Durham, J.J., Rouse, J.E., Moore, G.R., 1982. Reduction of water with zinc for hydrogen isotope analysis. Anal. Chem. 54, 993-995.

Craig, H., 1961. Isotopic variations in meteoric waters. Science 133, 1702-1703.

Craig, H., Gordon, L.I., 1965. Isotopic oceanography: deuterium and oxygen 18 variations in the ocean and the marine atmosphere. Atomic Energy Comm. Rep. NYO-3450-1, 277-374.

Devol, A.H., Quay, P.D., Richey, J.E., 1987. The role of gas exchange in the inorganic carbon, oxygen, and ${ }^{222} \mathrm{Rn}$ budgets in the Amazon River. Limnol. Oceanogr. 32, 235-248.

Epstein, S., Mayeda, T., 1953. Variation of $\mathrm{O}^{18}$ content of waters from natural sources. Geochim. Cosmochim. Acta 4, 213-224.

Geyer, W.R., Beardsley, R.C., Candela, J., Castro, B.M., Legeckis, R.V., Lentz, S.J., Limeburner, R., Miranda, L.B., Trowbridge, J.H., 1991. The physical oceanography of the Amazon outflow. Oceanogr. 4, $8-14$.

Gibbs, R.J., 1970. Circulation in the Amazon River estuary and adjacent Atlantic Ocean. J. Marine Res. 28, 113-123.

Gordon, A., 1986. Interocean exchange of thermocline water. J. Geophys. Res. 91, 5037-5046.

Lentz, S.J., 1995. The Amazon River Plume during Amasseds: Subtidal current variability and the importance of wind forcing. J. Geophys. Res. 100, 2377-2390.

Lentz, S.J., Limeburner, R., 1995. The Amazon River plume during Amasseds: spatial characteristics and salinity variability. J. Geophys. Res. 100, 2355-2375.
Limeburner, R., 1992. Unpublished presentations. Amasseds workshop, Stony Brook, 7-8 June 1992.

Limeburner, R., Beardsley, R.C., 1989. CTD observations on the north Brazil shelf during A Multidisciplinary Amazon Shelf SEDiment Study, Amasseds, August, 1989, WHOI Tech. Rep. 89-53, Woods Hole Oceanogr. Inst., Woods Hole , Mass. pp. 133.

Longinelli, A., Edmond, J.M., 1983. Isotope geochemistry of the Amazon Basin: a reconnaissance. J. Geophys. Res. 88, 3703-3717.

Moore, W.S., Astwood, H., 1991. Advection of Amazon water into the Atlantic Ocean. In: Rine, J.M., Nittrouer, C.A (Eds.), Figures from Presentations (with abstracts) from Amasseds Session at AGU Fall Meeting, San Francisco - December 4, 1990. MSRC, SUNY, Stony Brook, N.Y., USA, pp. 191-200.

Neumann, G., 1969. Seasonal salinity variations in the upper strata of the western tropical Atlantic Ocean-I, sea surface salinities. Deep-Sea Res. 16, 165-177.

Paluszkiewicz, T., Chao, S., 1991. The dynamics of the Amazon outflow. In: Rine, J.M., Nittrouer, C.A (Eds.), Figures from Presentations (with abstracts) from Amasseds Session at AGU Fall Meeting, San Francisco - December 4, 1990. MSRC, SUNY, Stony Brook, N.Y., USA. pp. 220-229.

Oltman, R.E., 1968. Reconnaissance investigations of the discharge and water quality of the Amazon River. USGS Circular 552. USGS, Washington, D.C., pp. 16.

Reis, C., Tancredi, A.C.N.S., Matsui, E., Salati, E., 1977. Caracterizacao das aguas da regiao de Marajo atraves de concentracoes de O-18 e D. Acta Amazonica 7, 209-222.

Richey, J.E., Mertes, L., Dunne, T., Victoria, R.L., Forsberg, B.R., Tancredi, A., Oliveira, E., 1989. Sources and routing of the Amazon River flood wave. Global Biogeo. Cycles 3, 191-204.

Salati, E., Dall'Olio, A., Matsui, E., Gat, J.R., 1979. Recycling of water in the Amazon Basin: an isotopic study. Water Resour. Res. 15, $1250-1258$.

Salati, E., Matsui, E., Cervellini, A., Friedman, I., 1980. Isotope hydrology in Amazonia. Part I: $\delta^{18} \mathrm{O}$ and $\delta \mathrm{D}$ in river water. Energ. Nucl. Agric., Piracicaba 2, 101-132.

Salati, E., Vose, P.B., 1984. Amazon Basin: a system in equilibrium. Science 225, 129-138.

Sverdrup, H.U., Johnson, M.W., Fleming, R.H., 1946. The Oceans, their Physics, Chemistry and General Biology. Prentice-Hall, N.Y., USA, pp. 625-637.

Torgerson, T., 1979. Isotopic composition of river runoff on the U.S. east coast: evaluation of stable isotope versus salinity plots for coastal water mass identification. J. Geophys. Res. 84, 3773-3775. 